\title{
Effects of Revaprazan, a Novel Acid Antagonist, on Endocrine Function in Healthy Male Volunteers
}

\author{
Department of Pharmacology, Inje University College of Medicine and Department of Clinical Pharmacology, \\ Busan-Paik Hospital '; Clinical Trial Center ${ }^{2}$ and Department of Internal Medicine, Busan-Paik Hospital, \\ Busan, Korea; Yuhan Corp. ${ }^{4}$, Seoul, Korea \\ Ji-Hong Shon ${ }^{1,2}$, Ji-Young Ryu ${ }^{1}$, Yu-Eun Sunwoo', Jung-Hoon Jang ${ }^{2}$, \\ Eun-Young Kim $^{1,2}$, Young-Don Joo ${ }^{3}$, Sang-Young Seol ${ }^{2.3}$, Keun-Seog Song ${ }^{4}$, \\ Byoung-Seok Moon ${ }^{4}$, Sang-Aun Joo and Jae-Gook Shin ${ }^{1,2}$
}

=국문초록=

건강한 남성 지원자에서 위산분비억제제 레바넥스 ${ }^{\circledR}[$ revaprazan, YH1885] 정의: 반복투여가 내분비 기능에 미치는 영향 평가

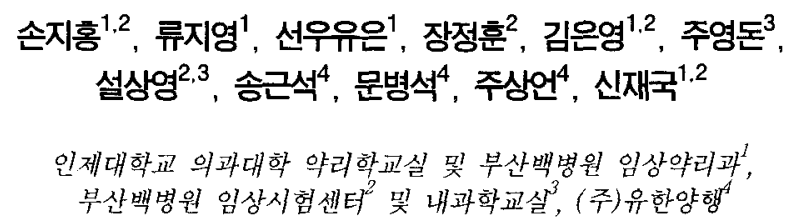

연구배경 및 방법: 차세대 위산분비 저해제(gastric acid-pump antagonist) revaprazan의 인체 내분비기능 에 대한 영향력을 평가하기 위하여 13 명의 건강한 한국인 남성 지원자를 대상으로 revaprazan $200 \mathrm{mg}$ 또는 위약을 1일 1회 7 일간 투여하기 전후로 내분비 기능을 평가하는 이중 눈가림법 무작위배정 교차시험 (double blind, randomized, crossover design)을 시행하였다. 투약 전후 혈청 tri-iodothyronine (T3), thyroxine (T4), thyroid-stimulating hormone (TSH), follicle-stimulating hormone (FSH), luteinizing hormone $(\mathrm{LH})$ 농도를 측정하였고, 시상하부-뇌하수체 호르몬 분비계에 대한 평가를 위해 thyrotropin-releasing hormone (TRH) 및 luteinizing hormone-releasing hormone (LHRH) 자극검사가 시행되었다.

연구결과: T3, T4, TSH, FSH, LH의 위약투여에 대한 revaprazan 투여 시 평균비( $90 \%$ 신뢰구간)는 1.04 $(0.996$ - 1.081), 1.00 (0.947-1.044), 1.27 (0.973-1.570), 0.92 (0.833-1.009), 0.97 (0.867-1.075)이었다. TRH$\mathrm{LHRH}$ 자극에 따른 TSH 와 LH 혈중농도변화는 위약과 revaprazan 투여기 간에 차이가 통계적으로 유의 하지 않았다 ( $p>0.05$, repeated-measures ANOVA).

결 론: 치료용량에서 revaprazan의 갑성선 및 성선호르몬분비계에 대해서는 영향을 미치지 않을 것으로 평 가되었으며, 환자에서 사용 시 내분비계 이상반응에 대해서는 안전할 것으로 기대되나, 시판 후 조사 통한 추가적인 안전성 자료 수집이 필요할 것으로 사료된다.

Key words: Revaprazan, Acid pump antagonist, Endocrine function.

\footnotetext{
책임저자 : 신재국

소 속 : 인제대학교 의과대학 약리학교실 및 약물유전체센터

주 소 : 부산광역시 부산진구 개금동 633-165 (우편번호 514-735)

전 화 : 051) 890-6709, Fax : 051) 893-7761, E-mail : phshinjg@inje.ac.kr
} 


\section{INTRODUCTION}

Proton pump inhibitors (PPIs), such as omeprazole, lansoprazole, pantoprazole, and rabeprazole, have been used extensively as the treatment of choice for stomach acid-related diseases, including peptic ulcer and gastroesophageal reflux. ${ }^{1}$ Proton pump inhibitors share the same benzimidazole structure but differ in terms of chemical substituents on this core structure. ${ }^{2}$ Drugs containing an imidazole ring in their chemical structures have previously been reported to interfere with endocrine hormone release, including defective cortisol synthesis by the adrenal cortex, abnormal gonad-hormone axis, and abnormal thyroid function. ${ }^{3-5}$ There are several reports of adverse endocrine effects, such as gynecomastia and impotence, in patients taking the prototype PPIs omeprazole and lansoprazole. $^{6-8}$ However, controlled clinical trials showed that short- or long-term treatment with omeprazole, lansoprazole, pantoprazole, and rabeprazole caused no significant effect on endocrine function in healthy volunteers. ${ }^{9-12}$

Revaprazan, 5,6-dimethyl-2-(4-fluorophenylamino)-4-(1-methyl-1,2,3,4-tetrahydro isoquinoline-2yl) pyrimidine hydrochloride, is a novel acid pump antagonist that was recently approved for marketing in Korea by the Korean Food and Drug Administration. It had good clinical efficacy for acid-related diseases and favorable safety profiles in clinical studies. ${ }^{13,14}$ It has no imidazole ring structure, unlike conventional benzimidazole PPIs (Fig. 1). In a preclinical chronic toxicity test of revaprazan $(0,5,20$, or $80 \mathrm{mg}$ / $\mathrm{kg} /$ day, for 26 weeks), one case of premature

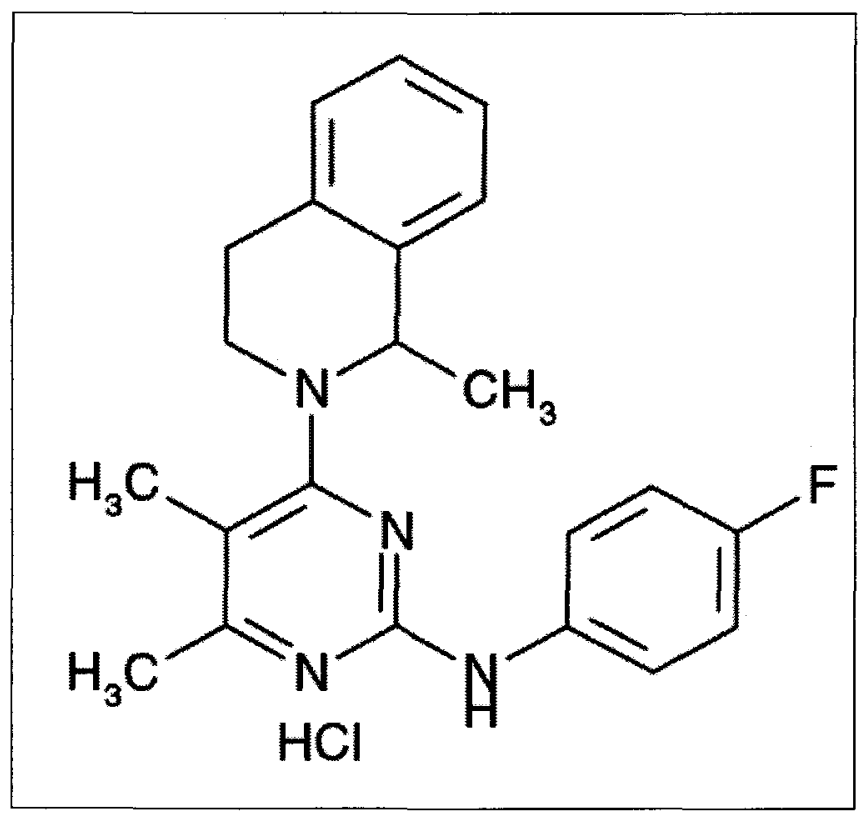

Figure 1. Chemical structure of revaprazan 
luteal lysis and a mild decrease in thyroid colloid were reported in rats treated with the highest dose of revaprazan $(80 \mathrm{mg} / \mathrm{kg} /$ day $)$. Based on these animal toxicity data, it was suggested that the inadequate luteal phase and decreased thyroid colloid caused by revaprazan be investigated further in relation to the abnormal secretion of LH and TSH from the anterior pituitary gland. Therefore, this study explored whether revaprazan has any effect on endocrine function, especially on anterior pituitary function, in normal healthy subjects.

\section{METHODS}

\section{Subjects}

Fourteen healthy male subjects were recruited. However, one subject withdrew during the crossover trial for personal reason. Therefore, the clinical study was completed in 13 subjects.
The age and body weight of the study subjects ranged from 19 to 24 years and from 52 to 78 $\mathrm{kg}$, respectively. All of the subjects were in good health as judged by their medical history, physical examination, electrocardiography, clinical laboratory tests, and endocrinological tests, including serum tri-iodothyronine ( $\left.\mathrm{T}_{3}\right)$, thyroxine $\left(\mathrm{T}_{4}\right)$, free $\mathrm{T}_{4}$, thyroid-stimulating hormone (TSH), follicle-stimulating hormone (FSH), luteinizing hormone (LH), and prolactin. The subjects were not allowed to take any drugs or to drink beverages containing alcohol or caffeine beginning 10 days before the study and continuing for the entire study period. All of the subjects provided informed, written consent before participating in the study. The study protocol was approved by the Institutional Review Board of Inje University, Busan-Paik Hospital, Busan, Korea. The trial was performed in accordance with the Declaration of Helsinki and the Guidelines for Good Clinical Practice (GCP).

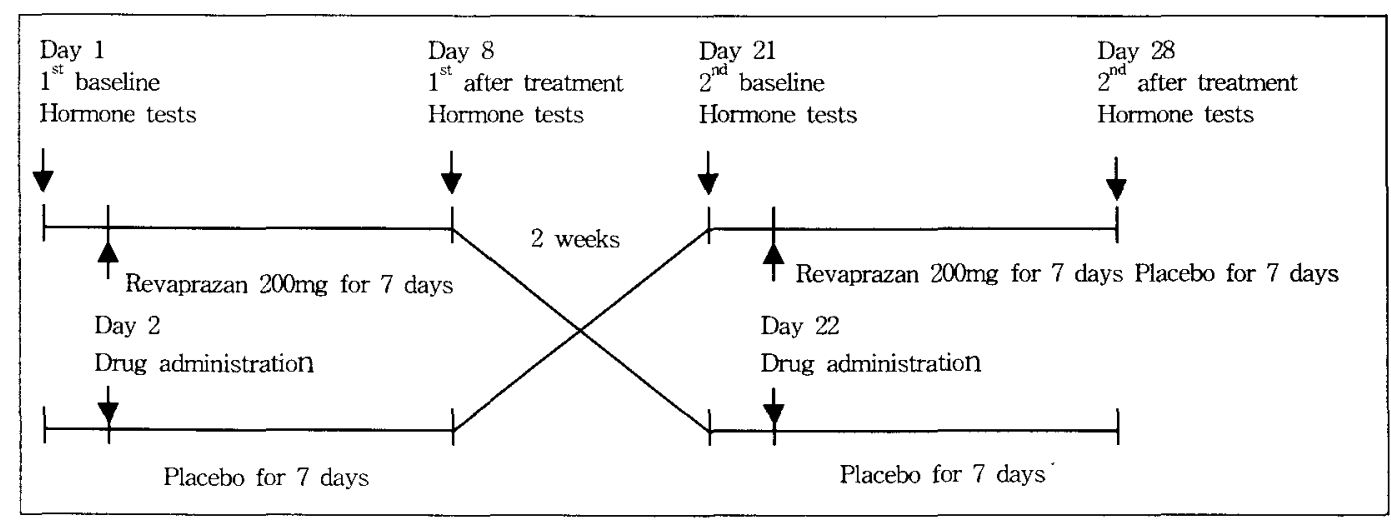

Figure 2. Schematic of the study design. The trial followed a randomized crossover design with a 2 -week washout period and 7 days of treatment with placebo or $200 \mathrm{mg}$ revaprazan. The hormone tests included the serum T3, T4, TSH, FSH, and LH levels and a TRH-LHRH stimulation test. 
— 손지홍 등 : 건강한 남성 지원자에서 위산분비억제제 레바넥스 ${ }^{\circledR}[$ revaprazan, YH1885] 정의 —

\section{Study design}

The study was designed to administer placebo or revaprazan for consecutive 7 days in a double -blind, placebo-controlled, randomized crossover manner with a 2-week washout period (Fig. 2). Each subject was given an oral dose of placebo or $200 \mathrm{mg}$ revaprazan (Yuhan Corp., Korea) 30 min before breakfast for 7 days, as $200 \mathrm{mg}$ revaprazan was the recommended daily dose from the phase II and III clinical trial phases. For evaluating compliance of dosing, telephone call was given to each subject around $9 \mathrm{AM}$ in every moming.

In each phase, pituitary function was assessed by measuring the serum $\mathrm{T}_{3}, \mathrm{~T}_{4}$, TSH, FSH, and $\mathrm{LH}$ levels one day before starting placebo or revaprazan (basal level, days 1 and 21) and on the last day of the dose (days 8 and 28). In addition, thyrotropin-releasing hormone (TRH) and luteinizing hormone-releasing hormone ( $\mathrm{LH}$ $\mathrm{RH}$ ) stimulation tests were performed in all study subjects in order to evaluate the change in the pituitary-endocrine axis. For this, the subjects were admitted to the Clinical Trial Center of Busan-Paik Hospital one day before the study day and fasted overnight. On the day of the endocrine function test in each phase, two consecutive blood samples were drawn at 8:30 a.m. and 9:00 a.m. via an indwelling catheter placed in a forearm vein, to determine the mean T3, T4, TSH, FSH, and LH levels. For the combined TRH and LHRH stimulation test, 0.4 mg TRH (Relefact TRH INJ $0.2 \mathrm{mg} / \mathrm{ml}$, Handok/Aventis Pharmaceuticals, Korea) and 0.1 mg LHRH (Relefact LH-RH INJ $0.1 \mathrm{mg} / \mathrm{ml}$,
Handok/Aventis Pharmaceuticals, Korea) were administered intravenously for $1 \mathrm{~min}$ to all subjects immediately after the blood sampling at 9:00 a.m. Blood samples were drawn at 0.5, 1, 1.5 , and $2 \mathrm{~h}$ after the injection of both TRH and LHRH.

Based on a medical examination and clinical laboratory tests, no subject complained of any adverse event or showed any significant changes in laboratory parameters throughout the study period, until 2 weeks after the last dose of revaprazan.

\section{Assay of hormone levels}

All samples used to determine serum hormone concentrations were stored at $-80^{\circ} \mathrm{C}$ and analyzed together at the end of the study. The levels of $T_{3}, T_{4}$, and TSH were determined using a chemiluminescent immunoassay with the ADVIA Centaur $\left({ }^{\circledR}\right.$ Immunoassay system (Bayer Diagnostics Division, NY, USA). FSH and LH were measured using a radioimmunoassay method with a gamma counter (Packard COBRA 5010, GMI, M, USA). The method of each hormone assay was validated according to daily protocol for quality control using various levels of $Q C$ materials.

\section{Data and statistical analyses}

To evaluate the endocrine effect of revaprazan, the basal hormone levels and the hormone levels on the day of the last dose were compared between the placebo and revaprazan treatments to evaluate the endocrine effect of revaprazan. In 
- J. H. Shon et al. : Effects of revaprazan on endocrine function -

addition, a direct comparison of the basal level and that after the 1-week treatment with revaprazan was conducted. Each hormone level was reported as the mean \pm S.D., with mean ratio and the 90\% confidence interval. The statistical significance of changes in the hormone levels between the two treatments and between before and after revaprazan treatment was analyzed using a paired t-test. For the TRH-LHRH stimulation test, repeated-measures ANOVA was used to evaluate the statistical significance of the LH and TSH concentrationtime profiles after TRH and LHRH administration between the placebo and revaprazan treatments. All statistical analyses were performed using SAS Version 8.1, and values of $p<0.05$

Table 1. Serum hormone concentrations before and after 7 days dosing with placebo or 200mg Revaprazan in healthy male subjects $(n=13)$

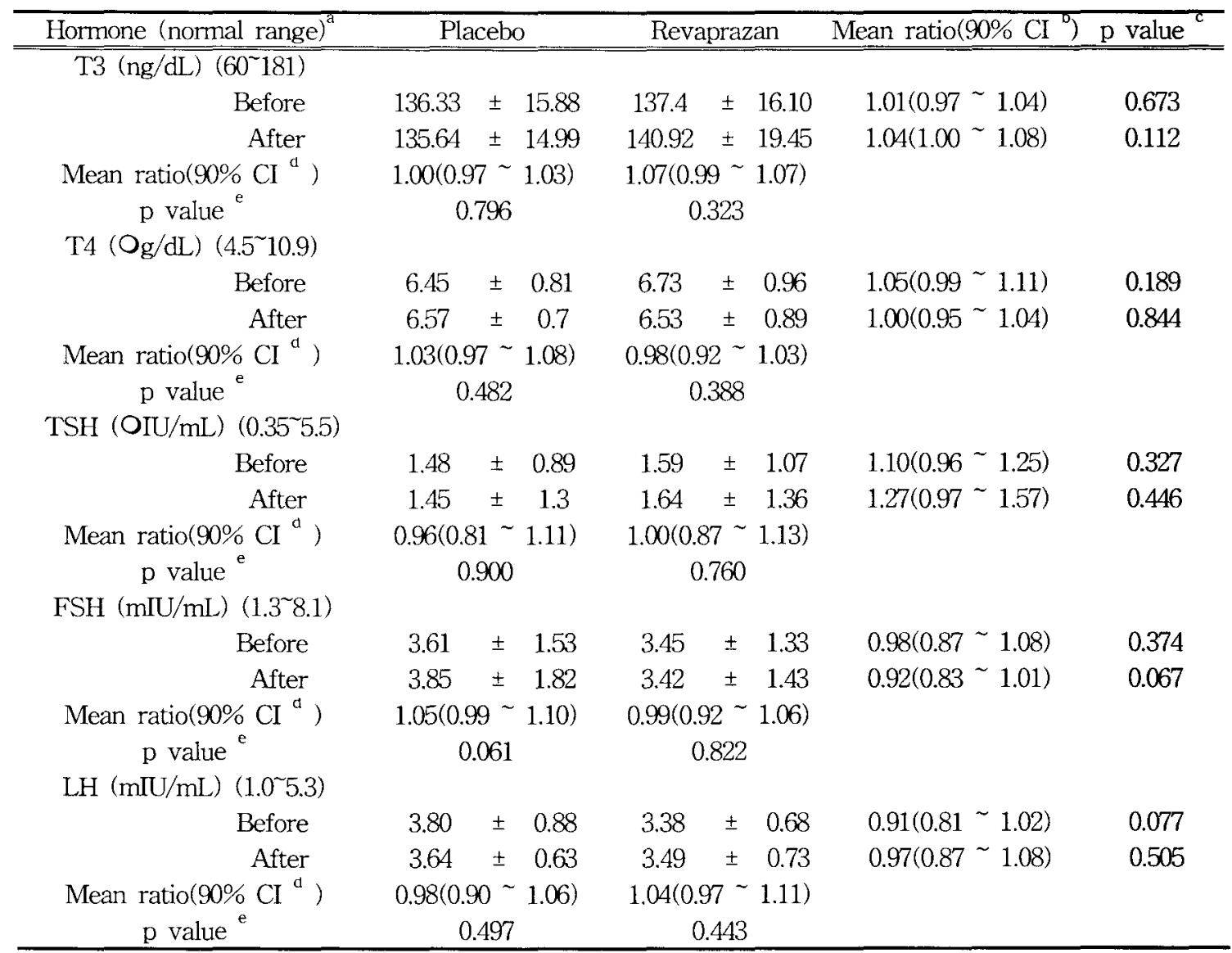

Values are presented as mean \pm standard deviation

${ }^{a}$ Reference range based on large series in Seoul Medical Science Institute, ${ }^{b} 90 \%$ confidence interval of mean ratio of placebo to revaprazan pretreatment, ${ }^{c}$ paired t-test between placebo and revaprazan phases, ${ }^{\mathrm{d}} 90 \%$ confidence interval of mean ratio of before to after pretreatment, ${ }^{\mathrm{e}}$ paired t-test between before and after treatment 


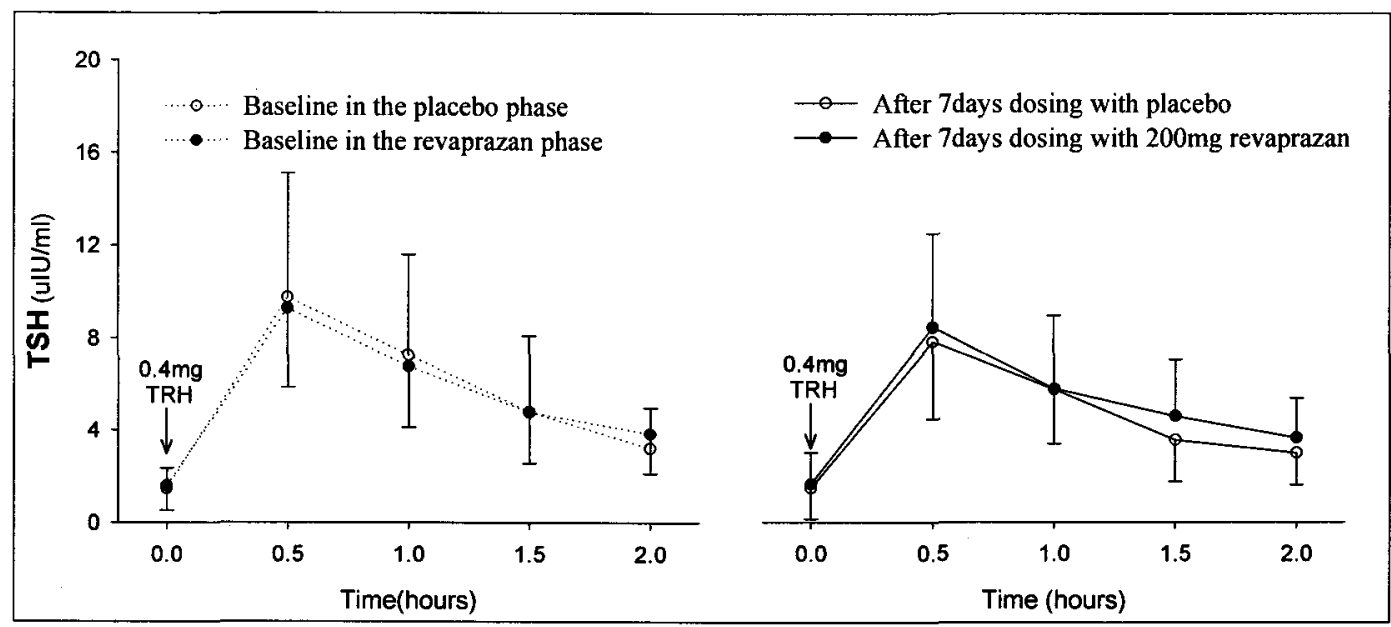

Figure 3. The mean serum TSH levels after intravenous stimulation with exogenous TRH(0.4mg) before(baseline) and after the 7-day treatment sith placebo or $200 \mathrm{mg}$ revaprazan in 13 healthy male subjects

were considered statistically significant.

\section{RESULTS}

The $\mathrm{T}_{3}$ and $\mathrm{T}_{4}$ levels in all of the subjects were within the normal ranges ( $\mathrm{T} 3: 60-181$ ng/dL; T4: $4.5-10.9 \mu \mathrm{g} / \mathrm{dL}$ for adults) before and after both treatments. The pre-treatment basal $\mathrm{T}_{3}$ and $\mathrm{T}_{4}$ levels did not differ significantly between the placebo and revaprazan treatments (T3, $p=0.673 ; \mathrm{T} 4, p=0.189$, Table 1). There was also no significant difference in the $\mathrm{T} 3$ and $\mathrm{T}_{4}$ levels between the placebo and revaprazan treatments after the 7-day treatment regimen ( $\mathrm{T} 3, p=0.112 ; \mathrm{T} 4, p=0.844$ ). In addition, there was no significant difference between the basal hormone levels and those after the 7-day treatment with revaprazan (Table 1).

The TSH level in all of the subjects was within the normal range (adults: 0.35-5.50 $\mu$
$\mathrm{IU} / \mathrm{mL}$ ) before and after both treatments. The TSH level did not differ significantly between the placebo and revaprazan treatments before or after the treatment regimen (before, $p=0.327$; after, $p=0.446$ ). In addition, there was no significant difference between before and after the revaprazan treatment (Table I).

In the TRH stimulation test, the injection of TRH was followed by an increase in the serum TSH level, which reached a maximum $(6.8 \pm 2.5$ times baseline) after $30 \mathrm{~min}$. After another 30 $\mathrm{min}$, the serum TSH level declined, returning to $2.7 \pm 1.2$ times the basal value after $2 \mathrm{~h}$. The pre-treatment basal TSH response to TRH administration did not differ significantly between the placebo and revaprazan treatments ( $p=0.951$, repeated-measures ANOVA). There was also no significant difference in the TSH response to TRH between placebo and revaprazan (200 mg) treatments after the 7-day treat- 


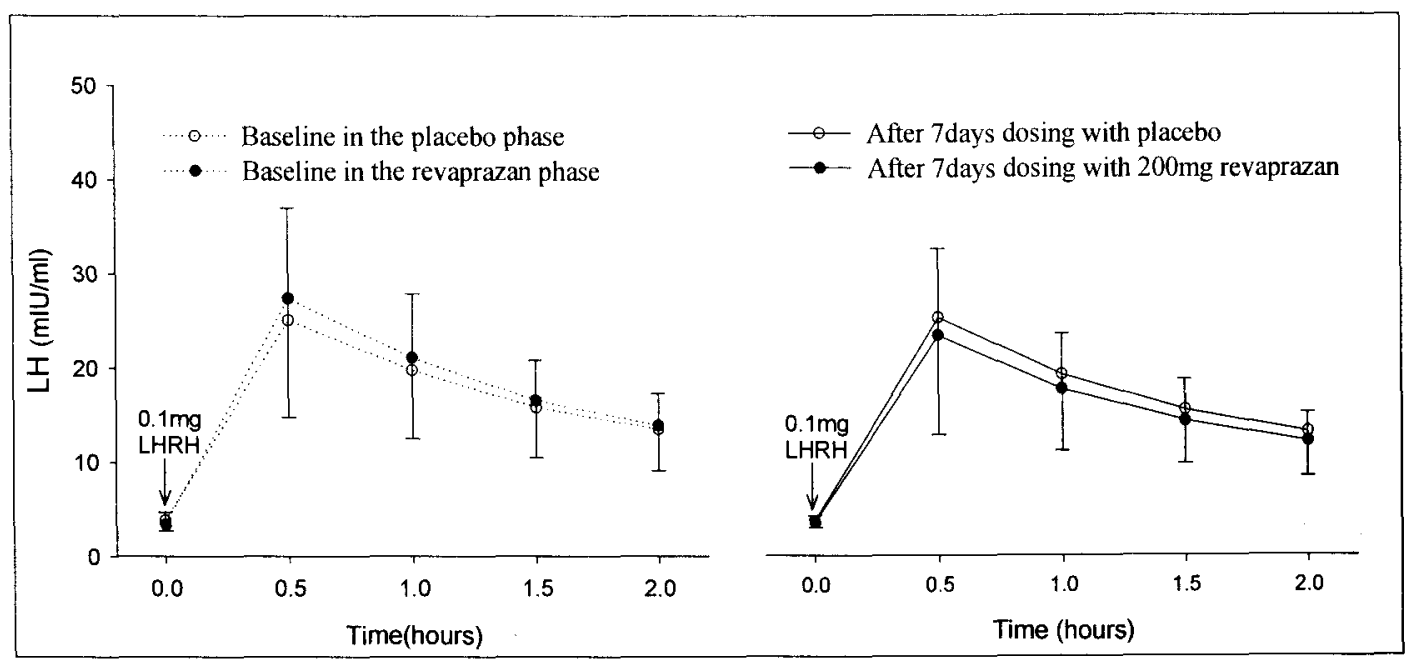

Figure 4. The mean serum LH levels after intravenous stimulation with exogenous LHRH (0.1 mg) before (baseline) and after the 7-day treatment sith placebo or $200 \mathrm{mg}$ revaprazan in 13 healthy male subjects.

ment regimen ( $p=0.302$; Fig. 3 ). Most of the subjects had a normal TSH response (peak value at $30 \mathrm{~min}$ : $5 \sim 10$ times baseline) to TRH before and after both treatments. ${ }^{15}$ In some of the subjects, the peak TSH levels following TRH stimulation were slightly below normal after the 7-day treatment with $200 \mathrm{mg}$ revaprazan, but similar results were also observed in the basal period before treatment or after the placebo treatment in some of the subjects.

The FSH and LH levels in all of the subjects were within the normal ranges (male FSH: 1.3$8.1 \mathrm{mIU} / \mathrm{mL}$; LH: $1.0 \sim 5.3 \mathrm{mIU} / \mathrm{mL}$ ) before and after both treatments. The pre-treatment basal FSH and LH levels did not differ significantly between the placebo and revaprazan treatments (FSH, $p=0.374 ; \mathrm{LH}, p=0.077$ ). There was no significant difference in the FSH and LH levels between the placebo and revaprazan (200 $\mathrm{mg}$ ) treatments after the 7 -day regimen $(\mathrm{FSH}, \mathrm{p}=$
$0.067 ; \mathrm{LH}, p=0.505$ ) or between before and after the revaprazan treatment (Table I).

In the LHRH stimulation test, the LH level reached a maximum (7.2 \pm 3.3 times baseline) 30 min after the injection of LHRH. Then, the LH level declined and returned to $3.7 \pm 1.2$ times basal values after $2 \mathrm{~h}$. No difference in the $\mathrm{LH}$ response to LHRH stimulation was found between the placebo and revaprazan treatments either before or after the treatment regimen (before, $p=0.682$; after, $p=0.498$; Fig. 4). A normal LH response (peak response: $3 \sim 10$ times baseline) to LHRH was observed in all subjects before and after both treatments.

\section{DISCUSSION}

Recently, the Korean Food and Drug Administration approved revaprazan, a novel acid pump antagonist, for the treatment of peptic ulcers. 
The present study did not find any significant differences in the $\mathrm{T}_{3}$ and $\mathrm{T}_{4}$ levels after revaprazan treatment or in the placebo phase. These results suggest that multiple doses of revaprazan have no effect on thyroid function. Seven days of $200 \mathrm{mg}$ revaprazan did not affect TSH, FSH, or LH levels, and there was no difference compared with the placebo phase. These results imply that multiple doses of revaprazan have no effect on basal anterior pituitary function. In the TRH stimulation test, the TSH response to TRH did not differ between the placebo and revaprazan treatments. In addition, in the LHRH stimulation test to evaluate the hypothalamic-pituitary gonadotropin axis, the LH response to LHRH did not differ between the placebo and revaprazan treatments. The pattern of the TSH and LH responses to TRH-LHRH administration was similar to previous results observed in healthy male subjects. ${ }^{16,17}$ Revaprazan treatment appeared to have no effect on anterior pituitary function in humans. Although a previous chronic toxicity test suggested that revaprazan alters pituitary function, as it caused premature luteal lysis and a mild decrease in thyroid colloid, our study clearly indicated that this new drug has no significant effects on pituitary function as determined by the serum thyroid and gonad hormone levels and the TRH-LHRH stimulation test of the pituitary endocrine axis.

Our results are similar to previous investigations of other currently prescribed PPIs, which have no effects on thyroid or gonadotropin endocrine function when given at the usual dose.9-12 There is some evidence that drugs with an imidazole nucleus, such as ketoconazole and cimetidine, affect the endocrine system, ${ }^{18-21}$ and PPIs that are benzimidazole derivatives have also been investigated for possible adverse endocrine effects. Omeprazole inhibits adrenocortical steroidogenesis in vitro and in vivo. ${ }^{22}$ There have been several reported cases of adverse endocrine effects, such as gynecomastia and impotence, in patients taking omeprazole. In those cases, however, the concentrations of prolactin and other regulating hormones were within the normal range. A previous clinical trial showed that omeprazole was unlikely to cause any significant interference with the endocrine system, including testosterone and prolactin levels. ${ }^{9}$ It was postulated that the endocrinological problems associated with omeprazole treatment might result from its potential to inhibit the cytochrome P450 (CYP) enzymes participating in the catabolism of endogenous steroidal hormones. $^{23,24}$ The inhibition of steroid metabolism by drugs may cause a hormone imbalance and result in endocrine abnormalities. ${ }^{25}$ It is possible that the effect of drugs on the estrogen catabolic pathway leads to gynecomastia and sexual dysfunction in men. ${ }^{26,27}$ In an in vitro study using human liver microsomes and recombinant CYP isoforms, revaprazan, unlike omeprazole, did not show an inhibitory potential on any CYP isoform. ${ }^{28}$ In addition, revaprazan does not possess an imidazole ring, and its chemical structure is unlike that of other PPIs, which are substituted benzimidazoles (Fig. 1). These facts suggest that revaprazan is unlikely to have any adverse drug reaction via a similar mechanism, such as endocrinological side effects mediated by 
- J. H. Shon et al. : Effects of revaprazan on endocrine function -

the CYP system.

The recommended dose of revaprazan is 200 mg once a day ( $34 \mathrm{mg} / \mathrm{kg}$ body weight), which is equivalent to $1 / 20$ of the revaprazan dose that was administered in the chronic toxicity test in rats ( $80 \mathrm{mg} / \mathrm{kg}$ body weight). Regardless of the species difference, the recommended dose of revaprazan in humans is relatively very low, and the chronic endocrine toxicity observed in the animal study seemed to be related to the high dose. However, clinically significant endocrine effects due to revaprazan treatment may still be possible, especially with treatment at higher doses producing higher serum concentrations. Revaprazan needs to undergo a continuous postmarketing evaluation in a larger population to determine its endocrinological safety.

In conclusion, revaprazan appears to cause no clinically significant effects on thyroid or gonad function with the repeated administration of the usual therapeutic dose. The absence of an effect of revaprazan on endocrine function in humans makes it favored over alternative drugs, such as other PPIs or some histamine receptor antagonists.

\section{Conflict of Interest}

None of the authors has any conflict of interest to declare with respect to the contents of this manuscript.

\section{References}

1. Robinson M. The pharmacodynamics and pharmacokinetics of proton pump inhibitors- overview and clinical implications. Aliment Pharmacol Ther. 2004;20:1-10.

2. Huber R, Kohl B, Sachs G, Senn-Bilfinger J, Simon WA, Sturm E. The continuing development of proton pump inhibitors with particular reference to pantoprazole. Aliment Pharmacol Ther. 1995;9:363-78.

3. Howden CW, Kenyon CJ, Beastall GH, Reid JL. Inhibition by omeprazole of adrenocortical response to $A C T H$ : clinical studies and experiments on bovine adrenal cortex in vitro. Clin Sci. 1986;70:99-102.

4. Curran PG, DeGroot LJ. The effect of hepatic enzyme-inducing drugs on thyroid hormones and the throid gland Endocr Rev. 1991; 12:135-50.

5. Mantovani A, Macri A. Endocrine effects in the hazard assessment of drugs used in animal production $J$ Exp Clin Cancer Res. 2002;21:445-56.

6. Santucci L, Farroni F, Fiorucci S, Morelli A. Gynecomastia during omeprazole therapy. $N$ Engl J Med. 1991;324:635.

7. Convens C, Verhelst J, Mahler C. Painful gynaecomastia during omeprazole therapy. Lancet. 1991;338:1153.

8. Cuervo MJR, Garcia OP, Sanchez SA, Garcia-Pando AC. Gynecomastia associated with the simultaneous use of cisapride and lansoprazole. Med Clin 2001;116:437-8.

9. MacGilchrist AJ, Howden CW, Kenyon CJ, Beastall GH, Reid JL. The effects of omeprazole on endocrine function in man. Eur J Clin Pharmacol. 1987;32:423-5.

10. Dammann HG, Bethke T, Burkhardt F, Wolf $\mathrm{N}$, Khalil H, Luehmann R. Effects of pantoprazole on endocrine function in healthy male volunteers. Aliment Pharmacol Ther. 1994;8:549-54.

11. Dammann HG, Burkhardt F, Wolf N. The effects of oral rabeprazole on endocrine and gastric secretory function in healthy volun- 


\section{- 손지홍 등 : 건강한 남성 지원자에서 위산분비억제제 레바넥스 ${ }^{\circledR}[$ revaprazan, YH1885] 정의 -}

teers. Aliment Pharmacol Ther. 1999 ;13: 1195-203.

12. Dammann HG, von zur Muhlen A, Balks HJ, Damaschke A, Steinhoff J, Hennig U, et al. The effects of lansoprazole, 30 or $60 \mathrm{mg}$ daily, on intragastric $p H$ and on endocrine function in healthy volunteers. Aliment Pharmacol Ther. 1993;7:191-6.

13. Han KS, Kim YG, Yoo JK, Lee JW, Lee MG. Pharmacokinetics of a new reversible proton pump inhibitor, YH1885, after intravenous and oral administrations to rats and dogs: hepatic first-pass effect in rats. Biopharm Drug Dispos. 1998;19:493-500.

14. Yu KS, Bae KS, Shon JH, Cho JY, Yi SY, Chung JY, et al. Pharmacokinetic and pharmacodynamic evaluation of a novel proton pump inhibitor, YH1885, in healthy volunteers. J Clin Pharmacol. 2004;44:73-82.

15. Carl AB and Edward RA. Tietz Textbook of Clinical Chemistry. 3rd ed Philadelphia: W.B. Saunders; 1999. 1486 and 1501.

16. Ormston BJ: Clinical effects of TRH on TSH release after intravenous and oral administration in normal volunteers and patients with thyroid disease. Front Horm Res. Basel, Karger, 1972; vol. 1; 45-75.

17. Schwarzstein L, de Laborde NP, Aparicio NJ, Turner D, Mirkin A, Rodriguez A, et al. Daily variations of FSH, LH and testosterone response to intravenous luteinizing hormone- releasing factor in normal men. $J$ Clin Endocrinol Metab. 1975;40:313-7.

18. English HF, Santner SJ, Levine HB, Santen RJ. Inhibition of testosterone production with ketoconazole alone and in combination with a gonadotropin releasing hormone analogue in the rat. Cancer Res. 1986;46:38-42.

19. Kohan SL, Guillen CE, Pardes EM, Junco M, Soto RJ, Sartorio GC. Effects of ketoconazole on the iodide uptake by FRTL-5 cells. Acta
Endocrinol. 1992;127:449-53.

20. Kenyon CJ, Fraser R, Birnie GG, Connell JM, Lever AF. Dose-related in vitro effects of ranitidine and cimetidine on basal and $A C T$ H-stimulated steroidogenesis. Gut. 1986 ;27: $1143-6$.

21. Pont A, Williams PL, Loose DS, Feldman D, Reitz RE, Bochra C, et al. Ketoconazole blocks adrenal steroid synthesis. Ann Intern Med. 1982;97:370-2.

22. Dowie LJ, Smith JE, MacGilchrist AJ, Fraser $\mathrm{R}$, Honour JW, Reid JL, et al. In vivo and in vitro studies of the site of inhibitory action of omeprazole on adrenocortical steroidogenesis. Eur J Clin Pharmacol. 1988;35:625-9.

23. Lindquist M, Edwards IR. Endocrine adverse effects of omeprazole. BMJ. 1992;305:451-2.

24. Jensen JC, Gugler R. Inhibition of human liver cytochrome $\mathrm{P}-450$ by omeprazole. $\mathrm{Br} J$ Clin Pharmacol. 1986 ;21:328-30.

25. Satoh T, Fujita KI, Munakata H, Itoh S, Nakamura K, Kamataki T, et al. Studies on the interactions between drugs and estrogen: analytical method for prediction system of gynecomastia induced by drugs on the inhibitory metabolism of estradiol using Escherichia coli coexpressing human CYP3 A4 with human NADPH-cytochrome P450 reductase. Anal Biochem 2000;286:179-86.

26. Thompson DF, Carter JR. Drug-induced gynecomastia. Pharmacotherapy. 1993;13:3745.

27. Satoh T, Munakata H, Fujita K, Itoh S, Itoh $\mathrm{S}$, Kamataki $\mathrm{T}$, et al. Studies on the interactions between drug and estrogen. II. On the inhibitory effect of 29 drugs reported to induce gynecomastia on the oxidation of estradiol at C-2 or C-17.Biol Pharm Bull. 2003;26:695-700.

28. Investigator brochure for revaprazan, $\mathrm{YH}^{-}$ 1885, clinical trials. 